\section{ANILINE OIL POISONING}

Editor of the Journal of Industrial and Engineering Chemistry:

At the present time many chemists in this country are be ginning the manufacture of aniline oil and it seems a good opportunity now to say a word of warning in regard to the danger to people engaged in this industry and to call attention to the precautions which should be taken to guard the health of the workmen.

The poisoning affects the victim first by an extreme languor which is followed by dizziness and then by unconsciousness, which comes on gradually. If an attack is light, a severe headache the next day is the only bad effect; a more severe case will have blue lips; and in a very severe case even the entire skin becomes blue and death may result.

The poison may be acquired in two ways: through the mucous membranes of the lungs and nose, or directly through the skin. In manufacturing aniline on a large scale the packing around the shaft and other joints of the aniline reducer are liable to leakage of steam and aniline water. Open tanks of aniline water, or of aniline itself, the evaporation of aniline and aniline water, which has been spilled on the floor, apparatus, receptacles and clothes of the workmen, all contribute aniline vapor to the air which must be breathed. Aniline vapor is heavy and accumulates near the floor, and it is, therefore, dangerous to work with the head near the floor. One of the writers had an experience illustrating this last statement while working for a few minutes kneeling down near an aniline reducer, which resulted in a severe headache and indigo-blue lips the next day. The accumulation of these aniline vapors in the building should not be permitted, and very thorough ventilation, especially near the floor, should be rigidly enforced.

The second method of acquiring aniline poisoning is through the skin, and judging from our experience, it would seem as if this source of poisoning, although apparently more gradual, is nevertheless very serious. The spilling of aniline oil and aniline water on the clothes, hands, and floor, where it wets the shoes, thus allowing the aniline water to come in contact with the skin, may result in a severe case of aniline poisoning. One of the writers was poisoned by having his hands wet with aniline water for one or two hours. Another case of aniline poisoning from having the feet of the workman moistened with the residual sludge from the aniline producer has also come to our attention.

The following precautions should be very carefully taken: I-There should be an adequate, thorough system of ventilation, both near the floor and near the ceiling. It is advisable to make the building in the form of a shed, with removable sides.

2-The floor should be made of some waterproof, impervious material with suitable drains so that the entire premises can be thoroughly flushed out. This flushing should be done often enough to prevent the accumulation of aniline residues.

3-Great care should be taken to keep tight glands and joints wherever aniline water is likely to escape. All tanks containing aniline water should be tightly covered.

4-Employees should be cautioned not to spill liquids containing aniline on their clothes and not to allow them to come in contact with their skin. Scrupulous cleanliness is an important factor for the preservation of the health of the employees.

There is one other precaution which it is advisable to take: never leave a man in your plant absolutely alone. Should he be overcome by aniline fumes, he may drop on the spot and be killed by the continued presence of the poisonous vapors. There should always be another man within call, who can come to the assistance of any one in distress and take him out into the fresh air for further treatment.

531 Grosvenor BuILding
PROVIDENCE, RHODE ISLAND

Augustus H. FISKE April 10, 1916

\section{REDUCTION OF CUPROUS OXIDE IN INVERT SUGAR DETERMINATION}

Editor of the Journal of Industrial and Engineering Chemistry.

Aug. Wedderburn recently described a method of reduction of copper oxide in vapor of alcohol for use in sugar analysis.? Dr. Charles A. Browne, N. Y. Sugar Trade Laboratory, advises the writer by letter that $\mathrm{E}$. Votocek and $\mathrm{O}$. Lexa ${ }^{2}$ proposed a similar method and that Vladimir Stanek, Prague Expt. Station, ${ }^{3}$ described an almost identical method. Abstracts of these methods have just reached me from the Chemists' Club Library.

Neither Mr. Wedderburn nor the writer could find references to this method in the available sugar works, hence we believed it original with Wedderburn. The foot-note in my Handbook ${ }^{4}$ was designed as evidence of the reliability of the method.

It is strange that this exceedingly simple, rapid and accurate method has not been published, so far as the writer can ascertain, in some of the numerous works on sugar that have appeared since Votocek's paper of 20 years ago.

THE CUban-AMERICAN SUgar Company New York ANd CUba, May 8, 1916

G. L. SPENCER

\section{BUREAU OF STANDARDS' ANALYZED SAMPLES}

The Bureau of Standards, Washington, D. C., now has ready for distribution a new sample of its Iron $D$, No, 6-b, replacing No. 6-a, which has been long out of stock. The composition of the new sample is: Carbon, 2.39; Graphite, I.79; Silicon, 2.59; Titanium, 0.077; Phosphorus, 0.531; Sulfur (grav.), 0.046; Manganese, I.54; Copper, 0.044; Chromium, 0.014; Vanadium, 0.025 ; Nickel, 0.026 . Until printed certificates can be had, a provisional certificate of analysis, without details, will be furnished with each sample issued.

$$
\begin{aligned}
& \text { NEW YORE CrTy } \\
& \text { May 16, } 1916
\end{aligned}
$$

\section{CEANOTHUS VELUTINUS (SNOW BRUSH) AS A SOURCE OF WAX AND TANNIN--CORRECTION}

In the paper by $\mathrm{Mr}$. Blakemore and myself as printed in This Journal, 8 (IgI6), 4II, the reading "creotic acid" throughout the arti.le is incorrect and should be changed to "cerotic acid." Also, the first sentence in the summary should read as follows: Ceanothus velutinus, a widely distributed plant, has been found to contain 7.3 per cent wax and 17.3 per cent tannin.

BERKELEX, CALIFORNIA Apri] 25,1916

Charlés C. Scalione

\section{GENERAL APPLICABILITY OF THE PAPER PULP FILTER, ETC.-CORRECTION}

In the article under the above title, This Journal, 8 (1916), 317, foot-note 4 should read: Biochem. Bull. 5 (1916), 87-94, instead of 4 (1915), 87-94.

Washington, D. C.

March 29, 1916

S. I. JoDIDI

E. H. KELLOGG

\section{ORGANIZATION FOR INDUSTRIAL PREPAREDNESS- - CORRECTION}

In the article under above title printed in ThIS JoUrnal, 8 (I9I6), 462, the name R. H. McKee, Orono, Me., should be changed to M. L. Griffin, Rumford, Me.

$$
\text { Chapei, HILL, N. C. }
$$$$
\text { April 29, } 1916
$$

Charies H. HERTY

1 Thrs Jourvat 7 (1915), 610. Spencer, "Handbook for Cane Sugar Manufacturers," 5th Ed., 240.

${ }^{2}$ Chem.-Zig. Repertoritum, 21, 324

3 Zuckerind. Böhmen, 32, 497; Chem. Abs., 2, 2315.

4 Loc, cit. 